\title{
PERKEMBANGAN SOSIAL DI KABUPATEN MAJALENGKA (Berdasarkan Data statistik 2004 - 2006)
}

\author{
Oleh H. Iwan Roswandi
}

Balai Pelestarian Sejarah Dan Nilai Tradisional Bandung

Jl. Cinambo No. 136 Ujungberung-Bandung 40294

Naskah diterima: 13 Juni 2011

Naskah disetujui: 1 Agustus 2011

\begin{abstract}
Abstrak
Tujuan penulisan ini adalah untuk mengetahui dan menganalisis bagaimana perkembangan pemerintahan Kabupaten Majalengka tahun 2006. Adapun metode penelitian yang digunakan adalah metode sejarah, melalui empat tahapan, yaitu heuristik (menemukan), kritik, interpretasi, dan historiografi. Perkembangan Kabupaten Majalengka (2004-2006) dapat diilustrasikan dari segi pemerintahan yang sebagian wilayahnya berada di daerah perbukitan. Hal ini memperlihatkan semakin beragamnya karakteristik yang ada, sehingga merupakan suatu modal untuk kemajuan daerahnya. Pengaruh pembangunan dan modernisasi berdampak jelas terhadap perubahan kehidupan politik, ekonomi, sosial, budaya serta pertahanan dan keamanan.

Tinjauan demografis menunjukkan bahwa jumlah penduduk Kabupaten Majalengka mulai tahun 2004 sampai dengan 2006 berdasarkan hasil Survei Sosial Ekonomi Nasional (Susenas) terus mengalami peningkatan. Jumlah penduduk perempuan lebih banyak daripada jumlah penduduk laki-laki. Untuk tahun 2004, kepadatan penduduk tertinggi berada di Kecamatan Kadipaten dan terendah di Kecamatan Kertajati. Seperti halnya dengan pertumbuhan penduduk, jumlah rumah tangga mengalami peningkatan dari 392.544 rumah tangga pada tahun 2005 menjadi 395.834 rumah tangga pada tahun 2006 atau meningkat menjadi 0,84\%. Dikondisikan dengan luas wilayah administratif $1.204,24 \mathrm{~km} 2$, maka rata-rata kepadatan penduduk di wilayah Kabupaten Majalengka pada tahun 2006 adalah sebesar 979 jiwa per km2. Kepadatan penduduk tertinggi berada di Kecamatan Jatiwangi dengan kepadatan $2.049 \mathrm{jiwa} / \mathrm{km}^{2}$ dan kepadatan terendah berada di Kecamatan Kertajati dengan kepadatan 325 jiwa per $\mathrm{km}^{2}$.

Salah satu faktor utama keberhasilan pembangunan di suatu daerah adalah tersedianya sumber daya manusia (SDM) yang berkualitas. Melalui jalur pendidikan pemerintah secara konsisten berupaya meningkatkan SDM penduduk melalui berbagai program. Seperti halnya program wajib belajar 9 tahun, Gerakan Nasional Orang Tua Asuh (GNOTA) dan berbagai program pendukung. Berdasarkan fakta jumlah penduduk yang cukup besar dari tahun ke tahun cukup sulit menyatukan komponen yang ada sehingga berdampak pada pelaksanaan pemerintahan yang kurang optimal.
\end{abstract}

Kata kunci: Kabupaten Majalengka, perkembangan sosial. 


\section{Abstract}

This research aims to analyse the development of Kabupaten Majalengka in 2006. The author conducted history method in four steps: heuristics, critique, interpretasition, and historiography. The conclusion is that the impacts of development and modernization can be clearly seen on the changes in socio-cultural, political and economical life of a society as well as on defense and security. Human resource is an important thing for the success of development, and education is very crucial in making it possible.

Keywords: District Majalengka, social development.

\section{A. PENDAHULUAN}

Secara geografis maupun demografis Kabupaten Majalengka merupakan wilayah Provinsi Jawa Barat yang cukup strategis karena sebelah timur berbatasan dengan Kabupaten Cirebon dan Kabupaten Kuningan. Demikian pula peningkatan jumlah penduduk yang tersebar dalam 23 kecamatan dan 331 desa mulai tahun 2004 sampai dengan tahun 2006 terus mengalami peningkatan rata-rata kepadatan penduduk mencapai 979 jiwa/km2 terutama di Kecamatan Kertajati. Keadaan tersebut telah menjadikan tenaga kerja yang merupakan modal bagi geraknya roda pembangunan. Jumlah dan komposisi tenaga kerja akan terus mengalami perubahan seiring dengan berlangsungnya proses demografi.

Jumlah penduduk yang terus meningkat dijadikan sebagai aset pembangunan karena salah satu tujuan utama pembangunan suatu wilayah adalah meningkatkan kesejahteraan rakyat atau dengan bahasa yang lebih luas yaitu mewujudkan masyarakat madani (civil society). Aspek kesejahteraan dicerminkan melalui peningkatan pendapatan dan daya beli masyarakat, aspek kemajuan diwujudkan melalui peningkatan pendapatan dan daya beli masyarakat, sementara aspek kecerdasan diwujudkan melalui perluasan partisipasi masyarakat untuk mengakses tingkat pendidikan yang lebih tinggi.

Salahsatufaktorutamakeberhasilan pembangunan di suatu daerah adalah tersedianya sumber daya manusia (SDM) yang berkualitas. Maka melalui jalur pendidikan pemerintah secara konsisten berupaya meningkatkan SDM penduduk melalui berbagai program. Seperti halnya program wajib belajar 9 tahun, Gerakan Nasional Orang Tua Asuh (GNOTA) dan berbagai program pendukung lainnya guna menciptakan SDM yang tangguh dan siap bersaing di era globalisasi.

Paradigma pembangunan telah mengalami perubahan karena tidak lagi menempatkan manusia sebagai subjek yang ikut mengambil keputusan, dalam terminologi pembangunan hal tersebut dikenal sebagai people centered development. Perubahan ini sangat penting untuk meningkatkan manusia secara kualitas, sehingga menjadi modal yang sangat berharga untuk pembangunan secara keseluruhan. Peningkatan kualitas manusia telah ditunjukkan dengan corak pembangunan saat ini, yaitu tidak hanya mementingkan pertumbuhan ekonomi melainkan juga mengarah pada peningkatan kualitas. Komitmen pemerintah untuk peningkatan kualitas 
sumber daya manusia telah diwujudkan sebagai salah satu kebijakan strategis, berbagai program dan kegiatan untuk mengakselerasi pembangunan kualitas manusia menjadi prioritas dalam Rencana KerjaPemerintah(RKP)maupun Rencana Kerja Pemerintah Daerah (RKPD).

Pembangunan manusia adalah upaya yang dilakukan untuk memperluas peluang penduduk untuk mencapai hidup layak, yang secara umum dapat dilakukan melalui peningkatan kapasitas dasar dan daya beli. Peningkatan kapasitas dasar adalah upaya meningkatkan produktivitas penduduk melalui peningkatan pengetahuan dan derajat kesehatan (ukuran pencapaian pembangunan manusia meliputi kelangsungan hidup/ kesehatan, pengetahuan dan daya beli). Peningkatan daya beli ditempuh melalui pertumbuhan ekonomi sehingga tercipta perluasan lapangan kerja. Kegiatan tersebut diaplikasikan pada bidang pemerintahan, penduduk, tenaga kerja dan transmigrasi, pendidikan, kesehatan dan keluarga berencana, pertanian, perdagangan, industri, koperasi, perhubungan, akomodasi, dan telekomunikasi. Dalam RKP pemerintah tahun 2004 s.d. 2006 di Kecamatan Majalengka diwujudkan dalam triple track strategy yaitu pro growth, pro poor and pro job.

Berdasarkan data yang diperoleh pada tahun 2006, diperoleh gambaran status daerah dan tipe pemerintahan. Berdasarkan perkembangan selama 3 tahun antara tahun 2003 s.d. 2006, terdapat peningkatan status daerah dengan tipe pemerintahan yang tetap, berikut penjelasannya. Pada tahun 2003, dari 424 desa terdapat 208 desa dengan status urban dan 216 desa dengan status rural. Berdasarkan tipe pemerintahan terdapat 412 tipe pemerintahan desa, 12 kecamatan. Pada tahun berikutnya, 2004, dari 424 desa terdapat 209 desa dengan status urban dan 215 desa dengan status rural. Berdasarkan tipe pemerintahan terdapat 412 tipe pemerintahan desa, 12 kecamatan. Pada tahun 2005, dari 424 desa terdapat 214 desa dengan status urban dan 207 desa dengan status rural. Berdasarkan tipe pemerintahan terdapat 412 tipe pemerintahan desa, 12 kecamatan.

\section{B, HASIL DAN BAHASAN}

Kabupaten Majalengka terletak di kawasan timur Jawa Barat yang berbatasan dengan Kabupaten Cirebon, Indramayu, Kuningan, Ciamis, dan Kabupaten Sumedang. Menurut hasil sensus penduduk tahun 1961 jumlah penduduk Kabupaten Majalengka sekitar 0,65 juta, meningkat menjadi 0,71 juta tahun 1971, dan 897.722 jiwa pada tahun 1980, sementara tahun 1990 telah mencapai di atas 1 (satu) juta $(1,03$ juta jiwa). Hasil sensus penduduk tahu 2000 sebesar 1.121.641 jiwa, Penduduk Kabupaten Majalengka pada tahun 2006 adalah sebanyak 1.179.136 jiwa terdiri atas 582.474 jiwa laki-laki dan 596.662 jiwa perempuan atau meningkat 0,84 $\%$ bila dibandingkan dengan jumlah penduduk sebelumnya.

Data tersebut di atas, menunjukkan bahwa jumlah penduduk perempuan terlihat masih tinggi dibandingkan jumlah penduduk laki-laki dengan sex ratio 97,62\%, dan berdasarkan data terakhir dari Susenas 2007 jumlah penduduk telah mencapai 1.188.189 jiwa dengan laju pertumbuhan penduduk 0,76 persen, ratio jenis kelamin 98,08 dan kepadatan penduduk 987 jiwa/km2. 
Secara kodrati sebenamya wanita dapat dikatakan sangat memegang fungsi sentral keluarga, yaitu sebagai ibu rumah tangga. Namun demikian, sumber daya ekonomi wanita tidak kalah dibanding pria. Keberadaan wanita dalam rumah tanggabukanhanya sekadarsebagaifungsi reproduksi saja, namun dapat berperan aktif dalam menopang ekonomi rumah tangga. Banyak penelitian menunjukkan bahwa wanita acap kali memberikan sumbangan yang besar bagi kelangsungan ekonomi. Konsep pemberdayaan wanita di dalam pembangunan yang sedang gencar didengungkan akhir-akhir ini, perlu benar-benar diimplementasikan dalam berbagai aspek kehidupan.

Kabupaten Majalengka adalah salah satu di antara kabupaten-kabupaten di Provinsi Jawa Barat yang mempunyai jumlah penduduk cukup padat. Penduduk merupakan faktor yang sangat penting dalam mekanisme perencanaan pembangunan. Jumlah penduduk yang besar dan berkualitas rendah hanya menjadi beban pembangunan, apalagi jika distribusinya tidak merata dan komposisi secara sosial dan budayanya beraneka ragam. Oleh sebab itu, untuk menunjang keberhasilan pembangunan yang bertujuan meningkatkan kesejahteraan masyarakat, perkembangan penduduk diarahkan pada pengendalian kualitas, pengembangan kualitas, serta pengerahan mobilitas sehingga mempunyai ciri dan karakteristik yang menguntungkan pembangunan suatu daerah khususnya di Kabupaten Majalengka.

Seperti halnya dengan pertumbuhan penduduk, jumlah rumah tangga mengalami peningkatan dari 392.544 rumah tangga pada tahun 2005 menjadi 395.834 rumah tangga pada tahun 2006 atau meningkat menjadi
$0,84 \%$. Dibandingkan dengan luas wilayah administratif $1.204,24 \mathrm{~km} 2$, maka rata-rata kepadatan penduduk di wilayah Kabupaten Majalengka pada tahun 2006 adalah sebesar 979 jiwa per $\mathrm{km} 2$. Kepadatan penduduk tertinggi berada di Kecamatan Jatiwangi dengan kepadatan $2.049 \mathrm{jiwa} / \mathrm{km}^{2}$ dan kepadatan terendah berada di Kecamatan Kertajati dengan kepadatan 325 jiwa per $\mathrm{km}^{2}$.

Komposisi penduduk Kabupaten Majalengka yang ditinjau dari kelompok umur (struktur umur dikelompokkan menjadi tiga kelompok, yaitu 00 14 tahun atau kelompok umur yang tidak produktif, $15-64$ tahun atau dikategorikan sebagai kelompok umur produktif/mampu melakukan kegiatan ekonomidandiatas 65 tahunataukelompok umur tidak produktif/sudah tidak mampu melakukan kegiatan ekonomi). Pada tahun 2005 penduduk pada kelompok 15 s.d. 64 tahun berjumlah 767.808 orang dengan proporsi sebesar $65,66 \%$, sedangkan kelompok umur 65 tahun ke atas berjumlah 70.401 orang dengan proporsi sebesar 6,020. Jika dibandingkan tahun 2004 ternyata kelompok umur 00 s.d. 14 tahun mengalami peningkatan, sedangkan kelompok umur 15 s.d. 64 tahun dan kelompok umur 65 tahun ke atas mengalami penurunan.

Data tersebut di atas, menunjukkan bahwa dengan menurunnya jumlah penduduk pada kelompok umur produktif, walaupun penurunannya kecil, akan berpengaruh terhadap perekonomian. Oleh karena itu semakin besar penduduk yang berusia produktif maka semakin baik pula kondisi perekonomiannya.

Kepadatan penduduk di masingmasing kecamatan juga menunjukkan ketidakmerataan. Hal ini disebabkan kondisi dan potensi masing-masing 
wilayah kecamatan yang tidak sama. Makin padatnya penduduk cenderung di pusat kota Kecamatan dan daerah perkotaan, yang ditandai banyak terdapat kegiatan-kegiatan ekonomi masyarakat di berbagai bidang usaha yang dapat memberikan lapangan pekerjaan seperti perdagangan, industri, pengangkutan, pertanian, pertambangan, pemerintahan, jasa-jasa, dan lain-lain. Dari gambaran potensi kependudukan tersebut di atas, diharapkan penduduk Kabupaten Majalengka bukan lagi hanya sebagai beban pembangunan tetapi lebih sebagai aset pembangunan.

Tenaga kerja adalah modal bagi geraknya roda pembangunan suatu negara. Adapun jumlah dan komposisi tenaga kerja akan terus mengalami perubahan seiring denganberlangsungnya proses demografi. Peningkatan jumlah penduduk umumnya diikuti pula dengan penambahan jumlah angkatan kerja yang tentunya menuntut peningkatan penyediaan lapangan kerja.

Dalam mengukur gambaran keadaan penduduk yang aktif secara ekonomi digunakan data angkatan kerja dari penduduk usia kerja. Angkatan kerja wanita di Jawa Barat dapat direfleksikan dengan melihat Tingkat Partisipasi Angkatan Kerja (TPAK), yang merupakan perbandingan kerja terhadap total penduduk usia kerja.

Tingkat Partisipasi Angkatan Kerja Perempuan di Kabupaten Majalengka menunjukkan peningkatan dibandingkan tahun sebelumnya $(52,66$ persen) walaupun masih cukup rendah dibandingkan TPAK laki-laki yang mencapai (86,39 persen). Sementara secara keseluruhan TPAK Kabupaten Majalengka adalah 69,06 persen. Hal tersebut menunjukkan bahwa kontribusi wanita dalam kegiatan ekonomi belum maksimal. Implikasinya, banyak wanita yang masih menjadi kelompok bukan angkatan kerja, misalnya mengurus rumah tangga. Diduga, pergeseran nilainilai budaya, terutama dalam hal bekerja secara ekonomis, yang terjadi di Jawa Barat belum terlalu tercapai. 1stilah bahwa yang mencari pekerjaan adalah kewajiban laki-laki masih kuat berakar dalam budaya kita.

Dilihat dari status pekerjaan, terdapat fenomena yang cukup menarik. Banyaknya pekerja wanita di Kabupaten Majalengka yang masih berstatus pekerja keluarga mencapai 41,00 persen, sementara pekerja keluarga laki-laki hanya 6 persen. Pada daerah yang masih berorientasi pertanian pada sektor utama, masih banyaknya pekerja keluarga wanita memberikan indikasi tentang peran ekonomi marginal dan belum dimanfaatkan secara optimal, karena umumnya pekerja keluarga tidak mendapatkan upah/gaji, atau sekalipun ada, balas jasa yang diterima sangat jauh dari memadai. Para pekerja keluarga wanita hanya membantu para kepala rumah tangga dan tidak mempunyai posisi tawar dalam pengambilan keputusan. Posisi laki-laki sebagai kepala rumah tangga masih sangat kuat sehingga masih dominan dalam pengambilan keputusan dalam masalah usaha maupun masalah rumah tangga.

Pendidikan sampai taraf tertentu merupakan suatu kebutuhan dari setiap manusia dalam upaya mencerdaskan kehidupan bangsa. Pendidikan tidak dapat dipisahkan dari usaha peningkatan mutu sumber daya manusia Indonesia, sehingga diperlukan peningkatan jumlah sarana pendidikan. 
Sementara itu di Kabupaten Majalengka sarana pendidikan yang tersedia meliputi sekolah yang kurang dari 5 (lima) tahun dan Diniyah, Sekolah Dasar, SLTP, SMU/SMK, dan Perguruan Tinggi. Penyebaran sekolah di Kabupaten Majalengka sudah cukup merata dan proporsional dengan jumlah penduduk secara umum. Jumlah siswa baru sangat dominan pada Sekolah Dasar Negeri, sedangkan siswa yang putus sekolah untuk tingkat SLTP masih sangat tinggi dan ini perlu segera diantisipasi apalagi bila dikaitkan dengan program wajib belajar 9 tahun.

Pada tahun 2004 tercatat bahwa luas lahan sawah di Kabupaten Majalengka sedikitmengalami penurunan dibandingkan tahun 2003, yaitu yang semula 50.937 ha menjadi 50.925 ha. Hal ini disebabkan adanya peralihan fungsi lahan dari sawah berubah menjadi tanah pekarangan atau perumahan. Berkaitan dengan masalah tersebut maka untuk luas lahan kering mengalami peningkatan sebesar 12 ha. Oleh karena itu, luas lahan kering mengalami peningkatan yaitu dari tahun 2003 seluas 69.487 menjadi 69.499 ha di tahun 2004 dan dapat dilihat bahwa peningkatan terjadi di luas lahan pekarangan/perumahan dan tegalan.

Pelaksanaan pembangunan pertanian pada tahun 2006 diarahkan untuk memperbaiki Sumber Daya Manusia (SDM) dan teknologi tepat guna secara optimal dan sekaligus mengupayakan perluasan kesempatan kerja dan peningkatan pendapatan petani yang pada akhirnya memeratakan pembangunan pedesaan dalam rangka memakmurkan masyarakat secara menyeluruh. Untuk mencapai tujuan tersebut dilakukan usaha-usaha penyuluhan untuk melaksanakan intensifikasi, ekstensifikasi, diversifikasi, dan rehabilitasi.

Tanaman pangan meliputi tanaman bahan makanan (padi-padian, jagung, umbi-umbian, dan kacang-kacangan), sayuran, dan buah-buahan. Kecamatan Majalengka secara keseluruhan memiliki luas tanah sawah sebesar 50.905 ha dan lahan kering seluas 69.519 ha sampai dengan tahun 2006 sebesar 120.424 ha dengan $100 \%$ menggunakan teknik pengairan irigasi teknis. Dalam produksi padi per kecamatan, Kecamatan Kertajati unggul dalam mengelola lahan sawah dan ladang terbesar dengan mampu menghasilkan 50.779 ton padi sawah dengan luas panen sebesar 9.657 ha dan untuk padi ladang sebesar 6.645 ton dengan luas panen 1.796 ha. Produksi ladang untuk Kabupaten Majalengka menghasilkan 7.453 ton untuk tahun 2005 dan sebesar 10.203 ton pada tahun 2006.

Pada tahun 2005, produksi padi gabah kering giling mengalami penurunan dari 537.977 ton menjadi 493.444 ton pada tahun 2006 atau sekitar $8,28 \%$. Penurunan produksi ini sejalan dengan berkurangnya luas panen dari 94.604 ha pada tahun 2005 menjadi 91.196 ha pada tahun 2006 atau sekitar $3,60 \%$ dengan luas tanaman 71.749 ha. Sementara itu di lain pihak produksi padi ladang mengalami peningkatan sebesar 36,90\%, hal ini sejalan dengan meningkatnya luas panen.

Kabupaten Majalengka pada tahun 2004 s.d. 2006 untuk tanaman palawija lainnya seperti kedelai rata-rata produksi sebesar 11,78 kuintal s.d. 14,00 kuintal, kacang hijau produksi sebesar 6,60 kuintal s.d. 8,20 kuintal, kacang 
tanah produksi sebesar 14,75 kuintal s.d. 13,09 kuintal, ubi kayu produksi rata-rata sebesar 143,41 kuintal s.d. 142,19 kuintal, ubi jalar produksi ratarata sebesar 140,91 kuintal s.d. 152,07 kuintal.

Untuk tanaman hortikultura terjadi perubahan. Luas panen sayuran pada umumnya sejalan dengan perubahan produksinya, namun untuk beberapa komoditas terjadi sebaliknya. Seperti halnya komoditas bawang daun, cabe besar, kacang panjang, dan kangkung, meskipun luas panennya menurun pada tahun 2006 tetapi produksinya mengalami peningkatan. Adapun untuk komoditas tomat dan wortel yang luas panennya mengalami peningkatan, produksinya mengalami penurunan.

Untuk melihat komoditas buahbuahan di Kabupaten Majalengka pada tahun 2006 adalah sebagai berikut: produksi rambutan sebesar 996,00 ton dengan rata-rata produksi 19,28 kuintal (terbesar wilayah Kecamatan Sukahaji, alpukat sebesar 3.675 ton dengan rata-rata produksi sebesar 59,78 kuintal (terbesar wilayah Maja), belimbing sebesar 105,00 ton dengan rata-rata produksi sebesar 19,67 kuintal (terbesar wilayah Argapura), duku/langsat/kokosan sebesar 74,60 ton dengan rata-rata produksi sebesar 133,93 kuintal (terbesar wilayah Sukahaji), durian sebesar 3.549,00 ton dengan rata-rata produksi sebesar 81,34 kuintal (terbesar wilayah Sindangwangi), jambu biji sebesar 500,30 ton dengan rata-rata produksi sebesar 26,20 kuintal (terbesar wilayah Jatiwangi), jambu air sebesar 464,00 ton atau rata-rata produksi sebesar 43,66 kuintal (terbesar wilayah Argapura), jeruk besar berproduksi 174,40 ton atau rata-rata produksi sebesar 207,13 kuintal (terbesar wilayah
Kecamatan Argapura), jeruk siam/keprok berproduksi 786,40 ton atau rata-rata produksi sebesar 110,82 kuintal (terbesar wilayah Kecamatan Lemahsugih), mangga sebesar 42.188,00 ton atau rata-rata produksi sebesar 50,39 kuintal (terbesar wilayah Kecamatan Kertajati), manggis produksi sebesar 26,20 ton atau rata-rata produksi sebesar 10,00 kuintal (terbesar wilayah Kecamatan Banjaran), nangka/cempedak produksi sebesar 3.607,20 ton atau rata-rata sebesar 38,76 kuintal (terbesar wilayah Kecamatan Rajagaluh mencapai 901,20 ton), nenas produksi sebesar 40,41 ton atau rata-rata produksi sebesar 60,95 kuintal (terbesar wilayah Kecamatan Sukahaji sebesar 27,90 ton), pepaya produksi sebesar 561,67 ton atau rata-rata sebesar 80,64 kuintal (terbesar wilayah Kecamatan Palasah sebesar 107,10 ton), salak produksi sebanyak 599,20 atau rata-rata produksi sebesar 66,93 kuintal (wilayah terbesar Kecamatan Sukahaji), sawo produksi sebanyak 480,20 ton atau ratarata produksi mencapai 26,60 kuintal (terbesar wilayah Kecamatan Sukahaji), sirsak produksi sebanyak 63,60 ton atau rata-rata produksi sebesar 26,58 kuintal (terbesar wilayah Kecamatan Majalengka), sukun produksi sebanyak 433,50 ton atau rata-rata mencapai 34,50 kuintal (terbesar wilayah Kecamatan Sukahaji).

Pada umumnya kegiatan pertanian merupakankegiatanyangberupabercocok tanam, pemeliharaan ternak, budidaya dan penangkapan ikan, penebangan kayu dan pengambilan hasil hutan serta perburuan. Data produksi diperoleh dari BPS dan Dinas Pertanian Tanaman Pangan Kabupaten Majalengka.

Dewasa ini industrialisasi merupakan suatu tolok ukur kemajuan 
suatu negara, apakah negara tersebut masuk ke dalam kategori negara maju, negara berkembang ataukah negara miskin. Negara-negara Eropa, Jepang, Korea merupakan beberapa contoh negara yang maju dalam sektor industrinya. Indonesia walaupun sedikit demi sedikit terus menggalakkan sektor ini.

Demikian pula sektor industri ini memegang peranan penting dalam peningkatan pembangunan ekonomi suatu daerah, karena sektor ini selain cepat meningkatkan nilai tambah juga sangat besar peranannya dalam penyerapan tenaga kerja. Selain itu, sektor ini pun merangsang kegiatan ekonomi sektor lainnya seperti sektor jasa, angkutan, dan perdagangan. Sebagai gambaran pada Produk Domestik Redional Bruto (PDRB) Kabupaten Majalengka bahwa sektor industri mempunyai peranan sebesar $17,56 \%$ dengan laju pertumbuhan sebesar 5,20\%.

Sehubungan dengan itu maka pembangunan industri diarahkan untuk mendorong terciptanya struktur ekonomi yang seimbang dan kokoh dalam rangka terciptanya landasan yang kuat untuk tumbuh dan berkembangnya atas kekuatan sendiri.

Kabupaten Majalengka merupakan daerah potensi pertanian maka pengembangan industri perlu diarahkan juga ke arah agroindustri sehingga keseimbangan pembangunan industri dan pertanian dapat berjalan secara mantap. Untuk pengklasifikasian industri yang dilakukan oleh Badan Pusat Statistik didasarkan pada jumlah tenaga kerja dengan standar sebagai berikut:

1. Industri rumah tangga, yaitu usaha dengan tenaga kerja kurang dari 5 (lima) orang.

2. Industri kecil, yaitu industri dengan tenaga kerja antara 5 s.d. 19 orang.

3. Industri sedang, yaitu usaha industri dengan tenaga usaha antara 20 s.d. 99 orang.

4. Industri besar, yaitu usaha industri dengan tenaga kerja di atas 100 orang.

Pada tahun 2003 jumlah industri besar di Kabupaten Majalengka sebanyak 14 (empat belas) perusahaan dan industri sedang sebanyak 348 (tiga ratus empat puluh delapan) perusahaan. Tenaga kerja yang terserap sebanyak 16.114 orang. Bila dilihat dari jenis produksinya, industri besar/sedang yang berada di Kabupaten Majalengka 91 \% merupakan industri genteng.

Perkembangan industri untuk tahun 2006 jumlah industri besar di Kabupaten Majalengka sebanyak 10 (sepuluh) perusahaan dan industri sedang sebanyak 346 (tiga ratus empat puluh enam) perusahaan. Tenaga kerja yang terserap sebanyak 15.293 orang. Masih tetap bertahan hingga saat ini jenis produksi industri besar/sedang di Kabupaten Majalengka sebesar 91\% merupakan industri genteng.

Pada tahun 2004 s.d. 2006 banyaknya perusahaan industri besar menurut jumlah tenaga kerja per kecamatan, Kecamatan Bantarujeg memiliki 1 perusahaan dengan jumlah tenaga kerja sebanyak 114 orang dan 122 orang (tahun 2006); Cikijing sebanyak 1 perusahaan dengan jumlah tenaga kerja 105 orang dan tahun 2006 tidak ada; Leuwimunding memiliki 1 perusahaan dengan jumlah 105 orang tenaga kerja dan 106 tenaga kerja (tahun 2006); Jatiwangi sebanyak 4 perusahaan dan 3 perusahaan (tahun 2006) dengan jumlah tenaga kerja 942 orang (2004) dan 949 
tenaga kerja (2006); Dawuan sebanyak 3 perusahaan (2004) dan 2 perusahaan (2006) dengan jumlah tenaga kerja 1.420 orang dan 691 orang tenaga kerja (2006); Panyingkiran sebanyak 1 perusahaan dengan jumlah tenaga kerja 146 orang (2004) tetapi tahun 2006 tidak ada; Jatitujuh tahun 2004 s.d. 2006 sebanyak 1 perusahaan dengan jumlah tenaga kerja 655 orang dan bertambah menjadi 716 orang (2006); Sumberjaya sebanyak 2 perusahaan dengan jumlah tenaga kerja 248 orang (2004) dan untuk tahun 2006 tidak ada; tahun 2006 untuk Kecamatan Ligung memiliki 1 perusahaan dengan jumlah tenaga kerja 124 orang.

Perusahaan industri sedang untuk Kecamatan Cikijing sebanyak 2 perusahaan dengan jumlah tenaga kerja 64 orang (2004) dan 2006 tidak ada; Kecamatan Cingambul sebanyak 2 perusahaan dengan jumlah tenaga kerja 82 orang (2004) dan tahun 2006 sebanyak 1 perusahaan dengan jumlah tenaga kerja 48 orang; Majalengka sebanyak 1 perusahaan dengan jumlah tenaga kerja 25 orang (2004) dan tahun 20062 perusahaan dengan jumlah tenaga kerja 51 orang; Cigasong sebanyak 1 perusahaan dengan jumlah tenaga kerja 80 orang (2004) dan tahun 2006 sebanyak 1 perusahaan dengan jumlah tenaga kerja 78 orang; Sukahaji sebanyak 13 perusahaan dengan jumlah tenaga kerja 474 orang (2004) dan tahun 2006 sebanyak 13 perusahaan dengan jumlah tenaga kerja 466 orang; Rajagaluh sebanyak 1 perusahaan dengan jumlah tenaga kerja 29 orang (2004) dan tahun 2006 sebanyak 1 perusahaan dengan jumlah tenaga kerja 32 orang; Leuwimunding sebanyak 3 perusahaan dengan jumlah tenaga kerja 144 orang (2004) dan tahun 2006 sebanyak 3 perusahaan dengan jumlah tenaga kerja 142 orang; Palasah sebanyak 11 perusahaan dengan jumlah tenaga kerja 272 orang (2004) dan tahun 2006 sebanyak 10 perusahaan dengan jumlah tenaga kerja 223 orang; Jatiwangi sebanyak 231 perusahaan dengan jumlah tenaga kerja 8.187 orang (2004) dan tahun 2006 sebanyak 231 perusahaan dengan jumlah tenaga kerja 8.252 orang; Dawuan sebanyak 44 perusahaan dengan jumlah tenaga kerja 1.380 orang (2004) dan tahun 2006 sebanyak 46 perusahaan dengan jumlah tenaga kerja 1.428 orang; Kadipaten sebanyak 1 perusahaan dengan jumlah tenaga kerja 60 orang (2004) dan tahun 2006 tidak ada; Ligung sebanyak 19 perusahaan dengan jumlah tenaga kerja 1.023 orang (2004) dan tahun 2006 sebanyak 20 perusahaan dengan jumlah tenaga kerja 1.095 orang; Sumberjaya sebanyak 19 perusahaan dengan jumlah tenaga kerja 559 orang (2004) dan tahun 2006 sebanyak 13 perusahaan dengan jumlah tenaga kerja 469 orang. Untuk lebih jelasnya lagi bisa dilihat tabel di bawah ini:

\section{Penduduk 10 Tahun ke atas menurut kegiatan utama Kabupaten Majalengka Tahun 2004-2007}

\begin{tabular}{|c||c|c||c||c||}
\hline Penduduk & 2004 & 2005 & 2006 & 2007 \\
\hline Usia Kerja & 963.639 & 939.535 & 872.051 & 901.587 \\
\hline \multirow{2}{*}{ Angkatan Kerja } & 546.327 & 571.412 & 543.608 & 622.618 \\
\cline { 2 - 5 } & $(56,69)$ & $(60,82)$ & $(62,34)$ & $(69,06)$ \\
\hline \multirow{2}{*}{ Bekerja } & 485.517 & 511.870 & 475.732 & 576.147 \\
\cline { 2 - 5 } & $(88,87)$ & $(89,58)$ & $(87,51)$ & $(92,54)$ \\
\hline \multirow{2}{*}{ Mencari Pekerjaan } & 60.810 & 59.542 & 67.876 & 46.471 \\
\cline { 2 - 5 } & $(11,13)$ & $(10,42)$ & $(12,49)$ & $(7,46)$ \\
\hline \multirow{2}{*}{ Bukan Angkatan Kerja } & 417.312 & 368.123 & 328.443 & 278.969 \\
\cline { 2 - 5 } & $(43,31)$ & $(39,18)$ & $(37,66)$ & $(30,94)$ \\
\hline
\end{tabular}

Sumber: Badan Pusat Statistik

Kabupaten Majalengka

(http://www.majalengkakab.go.id/) 


\section{Persentase penduduk menurut lapangan usaha Kabupaten Majalengka Tahun 2004-2007}

\begin{tabular}{|c|c|c|c|c|}
\hline "LAPANGAN USAHA & 2004 & 2005 & 2006 & 2007 \\
\hline Pertanian & 36,82 & 29,95 & 31,24 & 37,61 \\
\hline Pertambangan dan Penggalian & 1,45 & 2,29 & 0,67 & 0,35 \\
\hline Industri Pengolahan & 19,06 & 18,36 & 19,39 & 13,94 \\
\hline Listrik, gas dan air minum & 0,09 & 0,39 & 0,10 & 0,24 \\
\hline '"'Konstruksi & "'m, 49 & 7,93 & 5,36 & 5,35 \\
\hline Perdagangan & 23,83 & 26,15 & 26,65 & 26,61 \\
\hline Angkutan dan Komunikasi & 5,50 & 5,97 & 5,80 & 5,47 \\
\hline "Keuangan & 0,47 & 0,68 & 0,51 & 1,19 \\
\hline Jasa-jasa Lainnya & 7,89 & 8,28 & 10,27 & 9,23 \\
\hline
\end{tabular}

Sumber: Badan Pusat Statistik

Kabupaten Majalengka

(http://www.majalengkakab.go.id/)

Perkembangan pasar pada tahun 2004 sampai dengan 2007, di Kecamatan Lemahsugih sebanyak 7 pasar desa, Bantarujeg 3 pasar desa, Cikijing 1 pasar desa, Talaga terdapat 1 pasar Pemda, Maja hanya 2 pasar desa, Cigasong hanya memiliki 1 pasar pemda, Rajagaluh hanya memiliki 2 pasar desa, Leuwimunding memiliki 2 pasar desa, Jatiwangi memiliki 4 pasar desa, Kadipaten 1 pasar pemda, Kertajati memiliki 1 pasar desa, Jatitujuh hanya memiliki 1 pasar desa, Ligung memiliki 3 pasar desa, dan Sumberjaya hanya memiliki 1 pasar Pemda. Namun tahun 2006 untuk wilayah Kecamatan Sukahaji mulai memiliki 1 pasar desa, sementara untuk kecamatan Kadipaten bertambah 1 pasar desa.

Untuk beberapa kecamatan pada tahun 2004 sampai dengan 2006 banyaknya toko, supermarket/pasar swalayan/toserba, dan restoran/rumah makan/kedai makan seperti Lemahsugih memiliki 30 toko dan 107 toko (2006); Bantarujeg tidak ada toko tahun 2004 dan sebanyak 182 toko (2006); Cikijing memiliki 27 toko dan 2 supermarket
(2004), tahun 2006 memiliki 321 toko dan 2 supermarket; Cingambul tidak ada toko (2004) dan 2006 terdapat 119 toko; Talaga 28 pasar, 2 supermarket dan 1 restoran (2004), tahun 2006119 pasar; Banjaran tidak ada toko (2004) dan tahun 2006 terdapat 69 toko; Argapura tidak ada pasar (2004) dan 57 pasar (2006)dan 1 restoran, Maja tidak ada pasar (2004) dan tahun 2006 terdapat 279 toko ditambah 1 supermarket dan 7 restoran; Majalengka terdapat 2 supermarket (2004) tahun 2006 terdapat 698 toko, 2 supermarket dan 21 restoran; Cigasong terdapat 1 toko (2004), dan tahun 12006 terdapat 205 toko, dan 4 restoran; Sukahaji tidak ada toko (2004) dan 243 toko dan 1 restoran (2006); Rajagaluh ada 50 toko, 5 toserba (2004), dan 323 toko dan 6 supermarket (2006); Sindangwangi tidak ada toko (2004) dan tahun 2006 terdapat 112 toko ditambah 7 restoran; Leuwimunding tidak ada toko (2004) dan tahun 2006 terdapat 231 toko; Palasah tidak ada toko (2004) dan tahun 2006 terdapat 196 toko; Jatiwangi terdapat 69 toko da 2 toserba (2004), tahun 2006 terdapat 822 toko, 3 toserba dan 5 kedai makan (2006); Dawuan tidak ada toko (2004) dan 398 pasar dan 3 restoran (2006); Panyingkiran tidak ada toko (2004) dan 113 toko dan 1 restoran (2006); Kadipaten terdapat 53 toko, 4 toserba (2004), dan 462 toko, 4 toserba, 7 rumah makan (2006); Kertajati tidak ada toko (2004) dan tahun 2006 terdapat 173 toko; Jatitujuh tidak ada toko (2004), dan tahun 2006 terdapat 195 toko, 1 toserba, dan 1 restoran; Ligung terdapat 9 toko (2004) dan 213 toko (2006), Sumberjaya terdapat 1 toko (2004) dan 278 toko, 6 kedai makan (2006).

Perkembangan koperasi tahun 2004 sampai dengan 2006, sesuai data 
dari Dinas Koperasi, UKM, dan Investasi Modal Kabupaten Majalengka untuk masing-masing kecamatan memiliki 1 (satu) koperasi. Hanya Jatiwangi, Panyingkiran dan Kertajati memiliki masing-masing 2 koperasi unit desa. Selanjutnya untuk koperasi non Unit Desa Kecamatan Lemahsugih memiliki 18 menjadi 21; Bantarujeg 20 menjadi 27; Cikijing memiliki 21 menjadi 24; Cingambul 22 menjadi 9; Talaga 19 menjadi tetap; Banjaran 13 menjadi 14; Argapura 13 menjadi tetap; Maja 22 menjadi 23; Majalengka terdapat 103 menjadi 104; Cigasong terdapat 15 menjadi 17; Sukahaji 22 menjadi tetap; Rajagaluh ada 17 menjadi 20; Sindangwangi 8 menjadi 9; Leuwimunding 13 menjadi tetap; Palasah 13 menjadi 15; Jatiwangi 20 menjadi 21; Dawuan 24 menjadi 25; Panyingkiran 6 menjadi 7; Kadipaten terdapat 24 menjadi 25; Kertajati 19 menjadi 20; Jatitujuh 22 menjadi 24; Ligung terdapat 14 menjadi 15; Sumberjaya memiliki 16 koperasi non unit desa menjadi 18.

Pada tahun 2004 sampai dengan 2006 di Kabupaten Majalengka terdapat 9 sarana akomodasi yang kesemuanya merupakan penginapan / hotel bukan berbintang dengan jumlah kamar 192 buah dan 293 buah tempat tidur (2004) namun bertambah menjadi 296 buah tempat tidur (2006).

Perkembangan banyaknya penginapan mulai tahun 1990. Banyaknya penginapan 5, banyaknya kamar 90, dan banyaknya tempat tidur 155; tahun 1991 s.d. 1992 banyaknya penginapan 6, banyaknya kamar 102, dan banyaknya tempat tidur 162; Tahun 1993 banyaknya penginapan 6 , banyaknya kamar 125 , dan banyaknya tempat tidur 253; Tahun 1994 banyaknya penginapan 8 , banyaknya kamar 187, dan banyaknya tempat tidur 272; tahun 1995 banyaknya penginapan 8, banyaknya kamar 190, dan banyaknya tempat tidur 277; tahun 1996 banyaknya penginapan 8, banyaknya kamar 190 , dan banyaknya tempat tidur 300 , tahun 1997 sampai dengan 1998 banyaknya penginapan 9, banyaknya kamar 200, dan banyaknya tempat tidur 300, tahun 1999 banyaknya penginapan 9 , banyaknya kamar 163, dan tempat tidur 246; tahun 2000 banyaknyapenginapan 9 , banyaknya kamar 170, dan banyaknya tempat tidur 170 , dan banyaknya tempat tidur 252 ; tahun 2001 banyaknya penginapan 8 banyaknya kamar 161, dan banyaknya tempat tidur 215; tahun 2002 sampai dengan 2003 banyaknya penginapan 8 , banyaknya kamar 176, dan banyaknya tempat tidur 264; tahun 2004 banyaknya penginapan 9, banyaknya kamar 192, dan banyaknya tempat tidur 293; tahun 2005 banyaknya penginapan 9 , banyaknya kamar 192, dan banyaknya tempat tidur 296; tahun 2006 banyaknya penginapan 9, banyaknya kamar 192, dan tempat tidur 296.

Kebutuhan akan informasi dari tahun ke tahun terus meningkat sejalan peningkatan laju pembangunan ekonomi, untuk itu diperlukan pula peningkatan kualitas sarana dan pelayanan informasi. Dalam era modernisasi saat ini khusunya dalam sektor komunikasi banyak dikuasai oleh pasaran yang mengedepankan kecepatan, kemudahan dan terjangkau. Handpone adalah salah satu produk modernisasi dalam komunikasi, dengan mengandalkan produk SMS (Short Message Service) dimana semua pengguna dapat dengan mudah berkomunikasi secara cepat, mudah dan murah, bahkan saat ini Internet pun telah dapat di download oleh handphone 
sehingga layanan email lebih mudah dilakukan.

Dari berbagai kemajuan komunikasi saat ini, ternyata perkembangan/pertumbuhan pengiriman surat di PT. POS Indonesia (PERSERO) khususnya di Kabupaten Majalengka sangat berpengaruh terhadap penurunan yang sangat tajam pada tahun 2008 ini.

Dalam pemenuhan kebutuhan akan informasi, televisi merupakan sarana yang banyak digunakan oleh penduduk Kabupaten Majalengka, dimana pada tahun 2003 jumlah kepemilikan pesawat televisi di Kabupaten Majalengka telah mencapai 97.711 buah dan antene parabola sebanyak 6.199buah. Sedangkan jumlah layanan telekomunikasi yang berupa telepon otomat, ditambah dengan ketersediaan wartel / kios pone sebanyak 64 buah.

Untuk nilai penjualan benda pos mengalami penurunan yang sangat tajam (turun hampir $50 \%$ dan penjualan benda pos pada tahun 2005). Berdasarkan sumber data dari PT Pos Indonesia (Persero) Kabupaten Majalengka tahun 2005-2006, pengiriman surat, Pos Paket, Wesel Pos beserta nilainya dapat dijelaskan berikut ini.

Pengiriman surat pada tahun 2005 sebanyak 6.296.623 surat dibagi ke dalam dua kategori pengiriman surat dalam negeri sebanyak 6.122.792 surat dan pengirimanan surat luar negeri sebanyak 173.831 surat. Pengiriman surat dalam negeri tahun 2005 terdiri dan pengiriman biasa sebanyak 3.909.283 surat, pengiriman tercatat sebanyak 21.499 surat, pengiriman kilat sebanyak 940.671 surat. Pengiriman kilat khusus sebanyak 1.159.643 surat. Sedangkan pengiriman surat luar negeri terdiri dari surat biasa sebanyak 157.256 surat dan surat tercatat sebanyak 16.575 surat.

Pengiriman surat pada tahun 2006 sebanyak 768.647 surat dibagi ke dalam dua kategori pengiriman surat dalam negeri sebanyak 764.054 surat dan pengirimanan surat luar negeri sebanyak 22.593 surat. Pengiriman surat dalam negeri tahun 2006 terdiri dari pengiriman biasa sebanyak 393.229 surat, pengiriman tercatat sebanyak 2.734 surat, pengiriman kilat sebanyak 170.047 surat. Pengiriman kilat khusus sebanyak 180.044 surat. Sedangkan pengiriman surat luar negeri terdiri dan surat biasa sebanyak 18.419 surat dan surat tercatat sebanyak 4.174 surat.

Pengiriman paket pos pada tahun 2005 sebanyak 1.618 .566 paket yang terdiri dari paket pos dalam negeri sebanyak 1.375.940 paket dan pengiriman paket pos luar negeri sebanyak 242.626 paket. Paket pos dalam negeri tahun 2005 terdiri dari pengiriman paket biasa (pengiriman) sebanyak 266.094 paket dan paket biasa (penerimaan) sebanyak 576.960 paket. Sementara Paket kilat (pengiriman) dalam negeri sebanyak 322.376 paket dan peket kilat (penerimanaan) sebanyak 219.510 paket. Paket pos luar negeri terdiri dari paket pengiriman sebanyak 82.093 paket dan penerimaan sebanyak 159.533 paket.

Pengiriman paket pos pada tahun 2006 sebanyak 885.697 paket yang terdiri dari paket pos dalam negeri sebanyak 862.003 paket dan pengiriman paket pos luar negeri sebanyak 23.684 paket. Paket pos dalam negeri tahun 2006 terdiri dari pengiriman paket biasa (pengiriman) sebanyak 397.922 paket dan paket biasa (penerimaan) sebanyak 118.906 paket. Sementara Paket kilat (pengiriman) dalam negeri sebanyak 315.190 paket 
dan paket kilat (penerimanaan) sebanyak 29.985 paket. Paket pos luar negeri terdiri dari paket pengiriman sebanyak 3.937 paket dan penerimanaan sebanyak 19.747 paket.

Wesel Pos terdiri dari wesel biasa dan kilat, berikut penjelasannya. Pada tahun 2005, wesel biasa memperoleh pengiriman sebanyak 7.476 wesel. Nilai pengiriman sebanyak Rp 1.718.443.550 juta, jumlah penerimaaan sebanyak 20.835 wesel dan nilai penerimaan sebanyak Rp 7.071.940.651 juta. Pada tahun 2006, wesel biasa memperoleh pengiriman sebanyak 747 wesel. Nilai pengiriman sebanyak Rp 161.753.042 juta, jumlah penerimaaan sebanyak 1.925 wesel dan nilai penerimaan sebanyak Rp 974.725.282 juta.

Uraian tentang wesel kilat digambarkan sebagai berikut. Pada tahun 2005, wesel kilat memperoleh pengiriman sebanyak 170.111 wesel. Nilai pengiriman sebanyak Rp 58.739.593.396 juta, jumlah penerimaaan sebanyak 364.996 wesel dan nilai penerimaan sebanyak Rp 156.279.548.442 juta. Pada tahun 2006, wesel kilat memperoleh pengiriman sebanyak 24.576 wesel. Nilai pengiriman sebanyak Rp 9.731.136.959 juta, jumlah penerimaaan sebanyak 67.000 wesel dan nilai penerimaan sebanyak Rp 31.597.403.270 juta.

\section{PENUTUP}

Tinjauan demografis menunjukkan bahwa jumlah penduduk Kabupaten Majalengka mulai tahun 2004 sampai dengan 2006 berdasarkan hasil Survei Sosial Ekonomi Nasional (Susenas) terus mengalami peningkatan yang ditandai jumlah penduduk perempuan lebih banyak daripada jumlah penduduk laki-laki. Untuk tahun 2004, kepadatan penduduk tertinggi berada di Kecamatan Kadipaten dan terendah di Kecamatan Kertajati. Namun tahun 2006 kepadatan penduduk tertinggi berada di Kecamatan Jatiwangi dan terendah di Kecamatan Kertajati.

Secara administratif, pada akhir tahun 2006 Kabupaten Majalengka terdiri dari 23 kecamatan dan 331 desa (berstatus desa 318 dan berstatus kelurahan 13). Jumlah pemerintah terendah berdasarkan satuan Iingkungan setempat terdiri dari Rukun Warga sebesar 1.881 atau 5.483 Rukun Tetangga dengan rasio sebesar $2.91 \%$. Sebagian besar penduduk bermata pencaharian sebagai petani sesuai dengan besarnya luas lahan yang dipergunakan untuk pertanian. Lahan Iainnya dipergunakan untuk peternakan, perikanan dan perkebunan. Karena itu pengembangan industri perlu diarahkan juga ke argo industri sehingga keseimbangan pembangunan industri dan pertanian dapat berjalan secara mantap. Adapun industri terbesar dihasilkan dari genteng yang didapatkan dari Kecamatan Jatiwangi.

Dalam bidang pendidikan, sarana yang tersedia meliputi Diniyah, Sekolah Dasar, SMU/SMK dan Perguruan Tinggi. Pemerintah Kabupaten Majalengka terus mengejar ketertinggalan masyarakat di bidang pendidikan melalui kerjasama dan sosialisasi berbagai program, seperti Gerakan Cinta Almamater Sekolah Dasar (Genta Masekdas), Wajib Belajar 9 tahun (Wajar 9 tahun), Gerakan Nasional Orang Tua Asuh (GNOTA), dan Program Jaringan Perlindungan Sosial Bidang Pendidikan. Sedangkan upaya pelayanan kesehatan masyarakat dapat diperoleh secara merata dan murah. Sarana kesehatan terdiri dari 39 dokter umum, 
10 dokter gigi, 109 bidan Puskesmas, dan 295 bidan desa.

Perkembangan sarana ibadah senantiasa ditingkatkan yang diarahkan pada peningkatan akhlak untuk kepentingan bersama dan membangun masyarakat serta dapat mengatasi berbagai masalahyang dominan beragama Islam. Prasarana perhubungan berupa pengangkutan darat yang penting guna memperlancar kegiatan perekonomian. Tersedianya jalan yang berkualitas akan meningkatkan usaha pembangunan khususnya dalam upaya memudahkan mobilitas penduduk dan memperlancar lalu lintas barang suatu daerah ke daerah lain. Adapun sarana akomondasi yang tersedia, antara lain, penginapan/hotel bukan berbintang dengan jumlah kamar 192 buah dan 296 buah tempat tidur.

\section{DAFTAR PUSTAKA}

Badan Pusat Statistik. 2005.

Kabupaten Majalengka dalam Angka Tahun 2004, Majalengka:

BPS Kabupaten Majalengka.

2007.

Kabupaten Majalengka dalam Angka Tahun 2007, Majalengka: BPS Kabupaten Majalengka.

---------. 2006.

Indikator Kesejahteraan Rakyat Kabupaten Majalengka Tahun 2005, Majalengka: Kerjasama Badan Perencanaan Daerah Kabupaten Majalengka dengan
Badan Pusat Statistik Kabupaten Majalengka. 2008.

Indeks Pembangunan Manusia Kabupaten Majalengka Tahun 2007, Majalengka: Kerjasama Badan Perencanaan Daerah Kabupaten Majalengka dengan Badan Pusat Statistik Kabupaten Majalengka. 